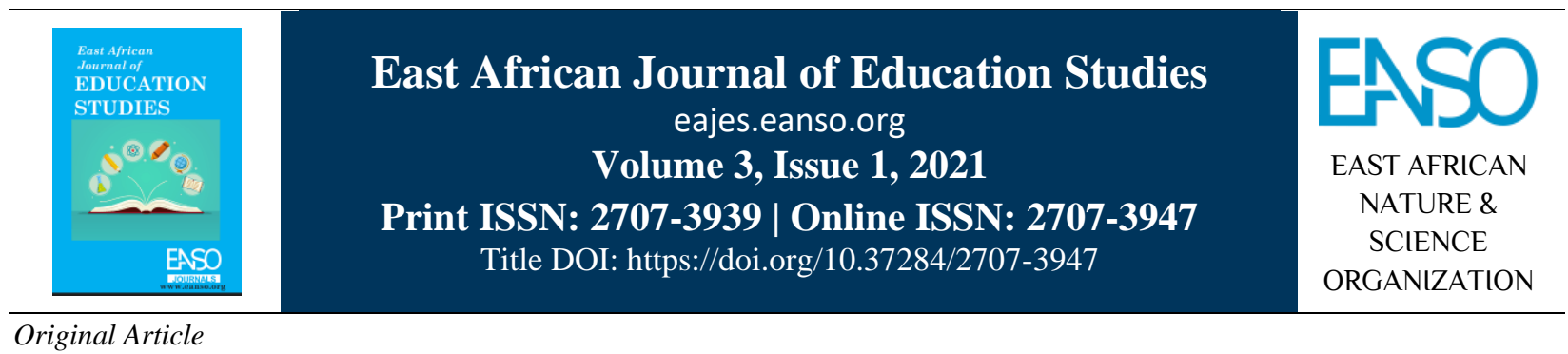

\title{
School Management Attitudes as Determinants of Implementation of Guidance and Counselling Services in Secondary Schools in Baringo Central Sub-County, Kenya
}

\author{
Gladys Jeruto Cheruiyot ${ }^{* 1}$ \& Dr. Bernard Chemwei, $P h D^{1}$ \\ ${ }^{1}$ Teachers Service Commission, Kenya, P. O. Box 49416 - 00100, Nairobi, Kenya. \\ $2 *$ Kirinyaga University, P. O. Box $143-10300$ Kerugoya, Kenya \\ *Author for Correspondence Email: bchemwei@yahoo.com.
}

Article DOI: https://doi.org/10.37284/eajes.3.1.304

\section{Date Published: ABSTRACT}

23 March 2021 Guidance and counselling constitute the best approach to help children and their families deal with life's frustrating issues. In the school context, guidance

Keywords: and counselling services assist the school to manage discipline and deal with the influence of social evils on learners and the learning environment.

School Management

Attitudes,

Implementation,

Guidance,

Counselling Services,

Secondary Baringo,

Kenya.

However, for guidance and counselling services to be effective in schools, several factors must be put in place. Among these factors, the key is school management support for guidance and counselling services. In recognition of this fact, the study examined the influence of the schools' management attitudes towards guidance and counselling on the implementation of guidance and counselling programmes in secondary schools in Baringo Central SubCounty. The study used the descriptive survey research method. It relied on a sample of 36 secondary schools with 36 principals and 72 teacher-counsellors. The research employed a questionnaire to collect the data. The collected data was then analysed using SPSS, version 22. The results of the study revealed that although most schools' managers had embraced and recognised the role of guidance and counselling in their schools, little time and resources were availed to sustain these important services. This situation had negatively affected the implementation of guidance and counselling in schools. Therefore, it was recommended that guidance should be conceptualised in a broader and more comprehensive and holistic view, incorporating vocational and other aspects of development

\section{APA CITATION}

Cheruiyot, G. J., \& Chemwei, B. (2021). School Management Attitudes as Determinants of Implementation of Guidance and Counselling Services in Secondary Schools in Baringo Central Sub-County, Kenya. East African Journal of Education Studies, 3(1), 52-60. https://doi.org/10.37284/eajes.3.1.304. 


\section{CHICAGO CITATION}

Cheruiyot, Gladys Jeruto, and Bernard Chemwei. 2021. "School Management Attitudes as Determinants of Implementation of Guidance and Counselling Services in Secondary Schools in Baringo Central Sub-County, Kenya". East African Journal of Education Studies 3 (1), 52-60. https://doi.org/10.37284/eajes.3.1. 304.

\section{HARVARD CITATION}

Cheruiyot, G. J., and Chemwei, B. (2021) "School Management Attitudes as Determinants of Implementation of Guidance and Counselling Services in Secondary Schools in Baringo Central Sub-County, Kenya", East African Journal of Education Studies, 3(1), pp. 52-60. doi: 10.37284/eajes.3.1. 304.

\section{IEEE CITATION}

G. J. Cheruiyot, and B. Chemwei, "School Management Attitudes as Determinants of Implementation of Guidance and Counselling Services in Secondary Schools in Baringo Central Sub-County, Kenya”, EAJES, vol. 3, no. 1, pp. 52-60, Mar. 2021.

\section{MLA CITATION}

Cheruiyot, Gladys Jeruto, and Bernard Chemwei. "School Management Attitudes as Determinants of Implementation of Guidance and Counselling Services in Secondary Schools in Baringo Central Sub-County, Kenya". East African Journal of Education Studies, Vol. 3, no. 1, Mar. 2021, pp. 52-60, doi:10.37284/eajes.3.1. 304.

\section{INTRODUCTION}

There are several reasons why schools must facilitate and ensure that they have fully functional guidance and counselling departments (Wanjiru, 2013). Guidance and counselling services ensure students are in a position to understand themselves in relation to the social and psychological world in which they live (Njoroge, 2014). Selfunderstanding, in this case, includes selfacceptance, developing personal decision-making competencies, and being able to resolve special problems (Gitonga, 2014). The guidance and counselling programme also helps provide occupational, educational and other information, which helps the students to formulate realistic educational and vocational plans (Wanjiru, 2013). In addition, guidance and counselling services assist students to grow through the identification and development of the qualities they need to modify and strengths they need to reinforce (Igoki, 2013). This includes assets in physical strength, mental capacities, and powers of sense, among others. Therefore, teachers and schools have the responsibility of ensuring that each student matures steadily along his own personal line (Njoroge, 2014). This means that guidance and counselling teachers should be responsible for planning the learning experiences, activities, attitudes and relationships so that as much as possible, each student's basic psychological needs are satisfied through the medium of education (Aura, 2003). Guiding and counselling students within the educational system also aim at maintaining order by promoting student discipline and developing their intellectual, social, physical and moral capacities to the full (Kamau, 2011).

The notable early developments in guidance and counselling services in institutionalised systems can be traced back to the development of experimental psychological laboratories by Wilhelm Wundt in Leipzig, Germany, in 1879 (Wangechi, 2012). This was later followed by similar experimental laboratories by Stanley Hall at John Hopkins University in 1883. The United States government was the first to recognise the role of guidance and counselling in an institutional set up (Wanjiru, 2013). The government undertook measures to ensure that guidance and counselling were fully grounded in the systems and process in institutions across the US. This was undertaken through a series of Acts of Congress. The notable ones are the George Reed Act of 1929 on vocational education; the George Dean Act of 1935 on funding for counselling; the George Barden Act of 1946 on vocational funding, and the National Defence Education Act (NDEA) of 1958 on school guidance systems and training for counsellors (Igoki, 2013).

In Kenya, the efficacy of guidance and counselling has highly been questioned owing to the perceived lack of goodwill on the part of the administration and learners to engage in fruitful dialogue. This situation calls for a thorough review of the existing mechanisms and channels of communication in schools to better understand and remedy the situation. In the recent past, Baringo Central SubCounty has experienced an increase in school unrests and indiscipline cases and this may be 
attributed to failures on the part of the guidance and counselling functions. The prevailing situation in Baringo Central Sub-County can be attributed to many factors among them being teachers' incompetence, workload as well as the attitudes of the teachers, school management and other stakeholders towards guidance and counselling in general.

\section{The Concept of Attitude}

Attitude is defined as the mental and neural state of readiness, organised through experience exerting a directive and dynamic influence upon the individual's response to all objects and situations with which it is related (Opondo, 2009). It is also defined as the relatively enduring orientation that individuals develop towards the various objects and issues they encounter during their lives and which they express verbally as opinions (Kanana, 2000). Nyaruai (2012) further argues that attitude is the mental disposition of an individual to act for or against a definite object. Muli (2012) further defines attitude as the learned predisposition to respond in a consistently favourable or unfavourable manner with respect to a given object. In this context, the concept of attitude denotes the sum total of a person's inclinations and feelings, prejudice or bias, preconceived notions, ideas, fears, threats and convictions about a specific topic (Njiiri, 2012).

Attitude has three components, namely cognitive, affective and behavioural (Muthee, 2004). The cognitive component involves the perceptions, beliefs or memories about objects and events (Owino, 2013). The affective component includes feelings and emotional responses to objects and events. It is the affective response as an emotional response that expresses an individual's degree of preference for an entity (Njiiri, 2012). The behavioural component concerns the intentions that predict the way in which an individual may behave in relation to an object or even (Owino, 2013). The behavioural intention is a verbal indication or typical behavioural tendency of an individual. The cognitive response is a cognitive evaluation of the entity that constitutes an individual's beliefs about the object (Njuguna, 2013).

According to Nyaruai (2012), attitudes are formed through five components, namely through direct experience, through classical conditioning, through instrumental conditioning, and through observational learning and modelling. The direct experience relates to the straight interaction with the object or subject, leading to the development of a liking or disliking of the object. Classical conditioning is the process by which a reflex response becomes associated with a stimulus that would not naturally activate that behaviour (Otati, 2013). Instrumental conditioning is the conditioning of voluntary behaviour through the process of reinforcement and punishment. Observational learning and modelling are learning by imitating the behaviour of a model.

\section{School Management Attitudes and Implementation of Guidance and Counselling}

The attitude of the school management towards guidance and counselling has a significant impact on the implementation of the same in their schools. This is because school principals have a huge role to play in resource allocation and the policy direction of the school, which affect all subjects (Wanjiru, 2013). An attitude is a fairly stable opinion regarding a person, object or activity, containing a cognitive element. Indeed, attitudes have been found to affect the implementation and effectiveness of guidance and counselling services in the education sector (Igoki, 2013).

In schools where the school management does not appreciate the contribution of the guidance and counselling, the management places a little premium on the implementation of the same (Ngumbi, 2012). As a result, guidance and counselling teachers were openly critical and questioned the value of their positions, thus leading to less professional development and interest in the area (Wanjiru, 2013). The negative attitudes of school administrators also affect the provision of guidance and counselling services in schools, as such attitudes translate into a lack of adequate time availed for the purpose (Igoki, 2013). The prime task of a principal is to exercise leadership that results in a shared vision of the direction to be pursued by the school and to manage change in ways that ensure that the school is successful in realising its vision (Wanjiru, 2013). As a leader and a manager of change, the principal must support guidance and counselling in managerial roles, all of 
which, if done well, will lead to the success of guidance and counselling in secondary schools and achievement of the organisational goals (Aura, 2003). Ngumbi (2012) proposes that every management should adopt school improvement as its centre of gravity. This means that the principal, in making school-related decisions, should always have school improvement in mind. Proper implementation of guidance and counselling is a part of this improvement.

A principal as a leader and a manager of change should embrace guidance and counselling in planning, organising, directing, coordinating and controlling guidance and counselling programmers, all of which, if done well leads to the success of guidance and counselling and achievement of the organisational goals (Orenge, 2011). This implies that principals are at the centre of school improvement, and if they fail in this task, then the entire school fails. The roles of the principals in the school administration are clearly laid down. Among others, the principals are implementers of the policies and procedures of the government (Wanjiru, 2013). They are leaders of teams of professional educators; and managers of the supply and effective use of human resources (human, financial and material resources). As far as guidance and counselling are concerned, the support of the school principals is quite essential for the development, application and maintenance of counselling programs, as well as the success of the teacher counsellors and the programs. The school principal has a very strong influence on the school's counselling programme because establishing a positive working relationship between school management and the school counsellors is vital to the success of the counsellors (Orenge, 2011).

Many guidance and counselling teachers perceive themselves as change agents, consultants, crisis managers and group leaders (Wangechi, 2012). They recognise that having the support of the principal and other school administrators is a key element to the success of their performance (Ojwang, 2010). The school management support can make a difference in the success of counsellors in schools and lack of the administrators' support can make the counsellor's job extremely difficult. The school management is directly involved in the distribution of duties within the school (Aura,
2003). However, guidance and counselling teachers may often find themselves being handed other tasks in the school that leaves them with too little time for students and diminishes the effectiveness of the overall counselling programmes (Njoroge, 2014). Some principals are confused about the actual role of guidance and counselling teachers in the school. Such principals lack the knowledge of the formers' roles and duties. In some schools, counsellors are looked upon with suspicion by the school management (Igoki, 2013). The reason for this is because, by the nature of their work, counsellors tend to be too close to the students. Their main role in school is to handle the students' issues with confidentiality. As such, when information is kept from the school principals and he/she gets suspicious, conflicts are sure to arise between the principal and the teacher counsellor (Njimu, 2013).

\section{Statement of the Problem}

In every education system, guidance and counselling services are critical to the functioning of the entire system. They help to realise and maintain a healthy and motivated school workforce, appropriate student discipline and enable the students to make appropriate life decisions. In Kenya, guidance and counselling are mandated by the Ministry of Education as a requirement in schools. Moreover, teacher counsellors are appointed and posted to schools by the Teachers Service Commission (TSC). However, schools still experience a lot of problems relating especially to student indiscipline. Preliminary reports indicate that guidance and counselling programmes are not efficient for a number of reasons, among them being constraints of time, finances, negative attitudes from students, teachers, parents, and administrators and the challenges of the changing society. Other challenges affecting the guiding and counselling departments are poor training of the guidance and counselling teachers and low state of planning and support (Republic of Kenya, 2001).

The Report of the Task Force on Student Discipline and Unrest (Republic of Kenya, 2001) recognised the use of guidance and counselling in the management of student discipline in schools due to its proactive approach. The fact that guidance and counselling is a recognised means of discipline management in schools, and considering that it is an 
institutionalised aspect of the schooling system in Kenya, one is forced to call to question the delivery of counselling services in view of the lapse in students' discipline in Kenya. The fact that many schools nationwide are experiencing indiscipline cases in schools as evidenced by students' unrests, destruction of school property and drop-outs casts doubts on the implementation of guidance and counselling services. Not only are the unrests violent and destructive, but they are also premeditated and have caused maximum harm to human life (Nyamwange, Nyakan \& Ondima, 2012). This scenario suggests a lack of effective alternative strategies to contain student indiscipline and Baringo Central Sub-County is not an exception. The level of indiscipline in schools and social ills such as teenage pregnancy, drug addiction, alcoholism, school drop-outs and school strikes indicate an increasing need for proper guidance and counselling sessions in schools (Gikandi, 2012). Therefore, this paper examines the influence of the school management attitudes towards guidance and counselling on the implementation of guidance and counselling in secondary schools in Baringo Central Sub-County.

\section{MATERIALS AND METHODS}

The study was conducted in Baringo Central SubCounty. It used a descriptive research technique. The target population was all the secondary school teachers within the study area. At the time of the study, the Sub-County had 36 secondary schools with 72 guidance and counselling teachers. The research used all 36 schools. Out of the 367 teachers, the research purposively sampled the counselling teachers in the schools. All the 36 principals in these schools and a total of 72 counselling teachers (two from each school) were thus sampled. These gave a total sample of 108 respondents.

To collect data, a structured questionnaire was used. Once the filled questionnaires were collected, they were sorted out to eliminate those with incomplete responses. The questionnaires were then coded into the SPSS software version 22 for the purposes of data analysis. Both inferential and descriptive statistics were used in data analysis. The descriptive statistics used included the means, standard deviations and frequencies. Inferential statistics were used to determine the strength of the relationship between independent (causal) variables and dependent (effect) variables. Among the inferential statistics that will be used include correlations and multiple linear regressions.

\section{RESULTS AND DISCUSSION}

\section{Existence of Guidance and Counselling Departments in Schools}

The research sought to find out the state of the guidance and counselling departments in the schools. The findings were as shown in Table 1 .

\section{Table 1: Guidance and Counselling Department}

\begin{tabular}{lll}
\hline Status Questions & Yes F (\%) & No F (\%) \\
\hline We have guidance and counselling teachers in our school & $80(84.2)$ & $15(15.8)$ \\
I have benefited from guidance and counselling in my school & $75(78.9)$ & $20(21.1)$ \\
We receive support from my school principal when carrying out & $78(82.1)$ & $17(18.4)$ \\
guidance and counselling services in the school? & & \\
\hline
\end{tabular}

As indicated in Table 1, the majority (84.2\%) of the respondents indicated that there were guidance and counselling teachers in their school, while a few $(15.8 \%)$ did not have such teachers. Still, the majority (78.9\%) others had benefited from guidance and counselling while only $21.1 \%$ had not. Lastly, $82.1 \%$ said they received support from their school principals when carrying out guidance and counselling services in their schools, while $18.4 \%$ did not receive support.

\section{Frequency of Guidance and Counselling Services}

The research further sought to establish how often the school offered guidance and counselling 
services to students. The findings were as shown in Figure 1.

Figure 1: Frequency of guidance and counselling services

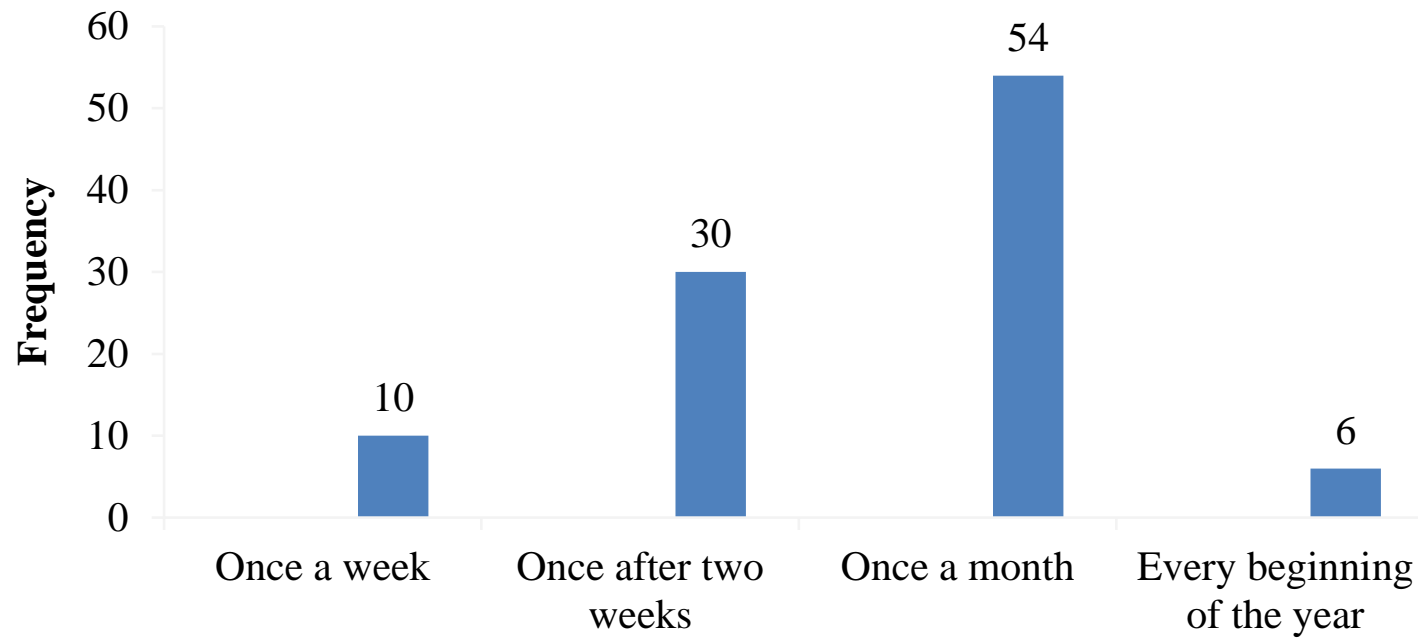

The findings in Figure 1 above show that the majority $(54 \%)$ of the schools offered guidance once a month. Other schools (30\%) offered the service twice a month. The least majority were schools that offered the service once a week at $10 \%$ and once per year at $6 \%$.

\section{School Management Attitude and Implementation of Guidance and Counselling}

Finally, the study sought to establish the extent to which the school management attitudes influence the implementation of guidance and counselling in Baringo Central Sub-County. The outcomes were as indicated in Table 2.

Table 2: School Management Attitudes and Guidance and Counselling

\begin{tabular}{llllll}
\hline Statement & $\mathbf{S A}(\mathbf{1})$ & $\mathbf{A}(\mathbf{2})$ & $\mathbf{N}(\mathbf{3})$ & $\mathbf{D}(\mathbf{4})$ & $\mathbf{S D}(\mathbf{5})$ \\
\hline $\begin{array}{l}\text { The school management embraces and recognises the role of } \\
\text { guidance and counselling in the school }\end{array}$ & $47 \%$ & $16 \%$ & $1 \%$ & $26 \%$ & $10 \%$ \\
$\begin{array}{l}\text { The school management often avails time and resources to } \\
\text { undertake guidance and counselling in the school }\end{array}$ & $1 \%$ & $8 \%$ & $1 \%$ & 35 & $55 \%$ \\
$\begin{array}{l}\text { The school management recognises the demands of guidance } \\
\text { and counselling while assigning duties }\end{array}$ & $23 \%$ & $23 \%$ & $3 \%$ & $28 \%$ & $23 \%$ \\
$\begin{array}{l}\text { The school management adheres to the aspects of } \\
\text { confidentiality between guidance and counselling teachers } \\
\text { and the students }\end{array}$ & & $29 \%$ & $1 \%$ & $34 \%$ & $21 \%$ \\
$\begin{array}{l}\text { The school management always avails resources necessary } \\
\text { for effective guidance and counselling programmes }\end{array}$ & $20 \%$ & $29 \%$ & $1 \%$ & $23 \%$ & $27 \%$ \\
\hline
\end{tabular}

Table 2 indicates that $63 \%$ of the respondents agreed that the school management embraced and recognised the role of guidance and counselling in their schools. Meanwhile, $36 \%$ disagreed with the statement implying that in a significant number of schools, the management had not embraced and recognised the role of guidance and counselling in their schools. Another greater majority (90\%) of the respondents, however, disagreed that the school management often availed time and resources to undertake guidance and counselling in the school. Only $9 \%$ agreed with the statement, meaning that, 
in most schools, the management often availed time and resources to undertake guidance and counselling in the school.

Moreover, Table 2 shows that $46 \%$ agreed that the school management recognised the demands of guidance and counselling while assigning duties. On the contrary, $51 \%$ disagreed with the statement. This indicated that there were more school managers who did not recognise the demands of guidance and counselling when assigning duties compared to those schools that did recognise these demands. Similarly, $44 \%$ of the respondents agreed that the school management adhered to the aspects of confidentiality between guidance and counselling teachers and the students. However, 55\% disagreed with the statement. Therefore, it was deduced that in many of the schools, school management did not adhere to the aspects of confidentiality between guidance and counselling teachers and the students.
Finally, $50 \%$ of the respondents disagreed that the school management always availed resources necessary for effective guidance and counselling programmes. Almost a similar (49\%) number of the respondents agreed with the statement. As such, it was concluded that some of the schools' management did not always avail resources necessary for effective guidance and counselling programmes.

\section{Correlation Analysis Results}

Correlation analysis was used to determine the degree of influence of the independent variables (school management attitudes) on the dependent variable (implementation of guidance and counselling services in schools). The level of significance chosen for the study was set at 0.05 . The results were summarised in Table 3 .

Table 3: Correlation for management attitudes and implementation of guidance and counselling

\begin{tabular}{lll}
\hline & $\mathbf{1}$ & $\mathbf{2}$ \\
\hline 1. School's management attitudes & 1 & 1 \\
2. Implementation of guidance and counselling & 0.555 \\
\hline Table 3 shows that school management attitudes & $\begin{array}{l}\text { such, lack of the administrators' support can make } \\
\text { strongly and positively influenced the } \\
\text { implementation of guidance, as indicated by a }\end{array}$ & $\begin{array}{l}\text { management is directly involved in the distribution } \\
\text { mandficient of } 0.555 .\end{array}$
\end{tabular}

These findings of the study agreed with those of Ngumbi (2012) who asserts that in schools where the school management lacks the requisite appreciation of the contribution of the guidance and counselling teachers in the school affairs, then the school management will place a little premium on the implementation of the same. In such schools, Ngumbi observes, the guidance and counselling teachers tend to become openly critical and question the value of their positions, thus leading to less professional development and interest in the area. Similarly, Igoki (2013) argues that negative attitudes by school administrators often affect the provision of guidance and counselling programmes in most schools. In his view, such attitudes translate into poor or non-provision of adequate time for guidance and counselling services and programmes in the school. Aura (2003) also found that school management support can make a difference in the success of counsellors in learning institutions. As

\section{CONCLUSION}

Based on the findings of the study, it was concluded that most schools' management has embraced and recognised the role of guidance and counselling in the school. Indeed, in most schools, the management recognises the demands of guidance and counselling while assigning duties. Most of the school managers also strive to avail resources necessary for effective guidance and counselling programmes. However, little time and resources are being availed to sustain these services. Moreover, many school managers do not adhere to aspects of confidentiality between guidance and counselling teachers and students. Lastly, there is a strong and positive relationship between school management attitudes and the implementation of guidance and counselling in schools. Therefore, resource availability explains significant variance in the 
implementation of guidance and counselling programmes in schools.

\section{RECOMMENDATIONS}

As a show of their support, school managers should provide resource materials and counselling or meeting rooms to teacher counsellors in their schools. Counsellor timetables for each school should also be developed and used. School managers should also adhere to the confidentiality of students' information obtained during counselling. Additionally, more resources should be devoted to guidance and counselling. The private sector should be enlisted to support the provision of student counselling in schools, considering that the state is unlikely to be able to afford to support school-based guidance programme.

\section{REFERENCES}

Gikandi, P. (2012). School Unrests n Mt. Kenya Region. A Semblance of Breakdown in Communication between Students and Administrators. The Standard Newspaper. Nairobi: Standard Media Group.

Gitonga, G. (2014). Institutional Factors Influencing Provision of Guidance and Counselling in Secondary Schools in Starehe District, Nairobi County (Unpublished Masters Project). University of Nairobi.

Igoki, J. N. (2013). Impact of Headteachers' Support on the Implementation of Guidance and Counselling in Secondary Schools in Mombasa District, Kenya (Unpublished Master's Thesis). Kenyatta University.

Kamau, W. G. (2011). Factors Considered in the Appointment of Guidance and Counseling Personnel in Public Secondary Schools in Kiambu West District, Kenya (Unpublished Master's Thesis). Kenyatta University.

Kanana, K. K. (2000). A Study of English Language Usage in Standard Five Classrooms of M/M West Meru Central District (Unpublished Masters Thesis). Kenyatta University.

Muli, P. (2012). Factors Influencing Choice of Physics in Public Secondary Schools in
Kangundo District, Machakos County (Unpublished Masters Thesis). Kenyatta University.

Muthee, J. (2004). Factors Influencing Career Aspirations Among Standard Eight Pupils in Kasarani Zone of Nairobi Province (Unpublished Master Project). Kenyatta University.

Ngumbi, E. (2012). Challenges Facing Teachers in Implementation Guidance and Counselling Services in Public Secondary Schools in Kikuyu Division in Kiambu District, Kenya (Unpublished Master's Project). University of Nairobi.

Njiiri, J. (2012). Effects of Learner's Attitude, Gender and School Type on English Language Performance; A Case Study of Thika West District (Unpublished Masters Project). Kenyatta University

Njimu, G. (2013). Perception of the Secondary School Principals and Teachers Towards Guidance and Counselling Services; A Case Study of Gatundu Division, Thika District, Kenya (Unpublished Master's Project). Kenyatta University.

Njoroge, D. N. (2014). The Role of Principals in Enhancing guidance aand Counselling Services in Secondary Schools; A Case Of Gatanga District, Muranga County (Unpublished Master's Project). Kenyatta University.

Njuguna, G. (2013). Factors Influencing the Use of E-learning in Public Universities in Kenya (Unpublished Masters Project). University of Nairobi

Nyamwange, C. B., Nyakan, P. O., \& Ondima, P. C. (2012). Assessment of challenges facing secondary school guidance and counselling teachers in Nyamira District, Kenya. Journal of Education and Practice, 3(16), 41-47.

Nyaruai, G. (2012). Factors Influencing Form Two Boys and Girls Choice of KCSE Subjects in Kieni Division, Nyeri North District, Kenya (Unpublished Masters Project). University of Nairobi. 
Ojwang, L. (2010). Problems Facing the Teacher Counsellor in the Implementation of Guidance and Counselling Programes (Unpublished Master's Project). Kenyatta University.

Okama, A. J. H. (2003). An Investigation into the Implementation Guidance and Counselling Services in Some Selected Secondary Schools in Butere-Mumias District, Kenya (Unpublished Master of Education Thesis). Kenyatta University.

Opondo, M. (2009). Factors Contributing to Low Enrolment of Students in Physics at Secondary School Level in Central Division, Garissa District, Kenya (Unpublished Masters Project). Kenyatta University.

Orenge, E. N. (2011). The Status of Career Guidance and Counselling Services for Students in Nairobi Province (Unpublished Masters Project). Kenyatta University.

Otati, M. (2013). Factors Affecting Student's Kenya Certificate of Secondary Education Performance in Art and Design in Secondary Schools of Nairobi County. (Unpublished Masters Project). Kenyatta University.

Owino, S. O. (2013). The Impact of E-learning on Academic Performance: A Case Study of Group Learning Sets (Unpublished Masters Project). University of Nairobi.

Republic of Kenya. (2001). Report f the Task Force on Student Discipline and Unrest. Nairobi: Government Printers.

Wangechi, C. M. (2004). Factors Affecting the Effectiveness of Guidance and Counselling Services in Kenyan Secondary Schools; A Case Study of Thika Town of Ruiru Educational Zone (Unpublished Master's Thesis). Kenyatta University.

Wanjiru, B. W. (2014). Institutional Management Practices for Enhanced Comprehensive Guidance and Counseling Services in Public Secondary Schools in Kahuro District, Murang'a County, Kenya. Unpublished Master's Project, Kenyatta University. 